\title{
DIVERSIFIKASI RESIDU PRODUK OLAHAN HOME INDUSTRY SIRUP JERUK KALAMANSI DI KABUPATEN BENGKULU TENGAH
}

\section{DIVERSIFICATION OF PROCESSED PRODUCTS RESIDUAL HOME INDUSTRY SYRUP ORANGE KALAMANSI IN BENGKULU TENGAH}

\author{
Oleh: \\ Evi Maryanti $^{1}{ }^{*}$, Dyah Fitriani $^{1}$, Fathnur Sani $^{2}$ \\ ${ }^{1}$ Jurusan Kimia, Fakultas Matematika dan Ilmu Pengetahuan Alam, Universitas Bengkulu \\ 2 Akademi Farmasi Al-Fatah Bengkulu \\ *corresponding author: evi.maryanti@unib.ac.id
}

\begin{abstract}
Community Service Activities for Residual Diversification of Processed Products Home Industry Syrup Kalamansi in Bengkulu Tengah has been completed. This activity aims to reduce the residual volume of unused Kalamansi syrup yields, the production of high value essential oils and various essential and economically valuable essential oil-based citrus oil products. In this activity we have conducted training on the way of extraction of essential oil from citrus peel residue and crude fiber (dregs) leftover of Kalamansi syrup using direct steam distillation method, followed by training of various essential oil based health products in form of aromatherapy roll oil, and Antiseptic liquid soap. From the results of the activities that have been done, the essential oil from the residue of Kalamansi syrup made of clear liquid smelling orange Kalamansi. It has also been produced several products made from active essential oil of orange Kalamansi such as wind oil roll on, liquid bath soap, lotion and liquid washing soap. The four products have a typical citrus scent Kalamansi, but need to be refined formula to produce a quality product and selling value.
\end{abstract}

Keywords: Citrus Kalamansi, Steam Distillation, essential oils, wind aromatheraphy oil.

\section{PENDAHULUAN}

Indonesia mempunyai sumber daya alam hayati yang sangat banyak dan beragam yang sampai saat ini masih belum bisa dimanfaatkan secara optimal. Diantara keanekaragaman hayati itu terdapat tanaman penghasil minyak atsiri yang sampai sekarang belum dapat dimanfaatkan secara maksimal. Indonesia menghasilkan 40-50 jenis tanaman penghasil minyak atsiri dari 80 jenis minyak atsiri yang diperdagangkan di dunia dan baru sebagian dari jenis minyak atsiri tersebut yang memasuki pasar dunia, diantaranya nilam, sereh wangi, gaharu, cengkeh, melati, kenanga, kayu putih, cendana, dan akar wangi. Meskipun Indonesia merupakan salah satu pemasok minyak atsiri dunia, tetapi kenyataannya ada sejumlah minyak atsiri yang juga diimpor. Padahal minyak atsiri yang diimpor tersebut dapat diproduksi oleh Indonesia sebagai contoh, bergamot, orange, 
lemon, lime, citrus, geranium, jasmine, lavender, peppermint, cornmint, dan vetiver (Muhtadin et al., 2013).

Jeruk Kalamansi (Citrofortunella microcarpa) atau dalam bahasa Melayu limau kesturi adalah jenis buah jeruk yang berkembang pesat di Kota Bengkulu, berbau harum, dan memiliki rasa yang asam ketika sudah masak, dan pahit ketika masih mentah. Jeruk Kalamansi banyak dibudidayakan di Kota Bengkulu, dan diproduksi secara besar-besaran untuk dijual dalam bentuk hasil olahan bernama Sirup Kalamansi (Sudarto, 2012). Sirup Kalamansi saat ini menjadi komoditas unggulan yang banyak diminati dan menduduki penjualan tertinggi dibandingkan makanan khas lainnya di sentra penjualan kerajinan dan makanan khas Kota Bengkulu.

Saat ini, sudah ada \pm sepuluh industri pembuatan sirup Kalamansi di provinsi Bengkulu. Dua diantaranya adalah home industry Bukit Bengkulu dan Putri Bengkulu yang berlokasi di Kabupaten Bengkulu Tengah. Dipilihnya kedua kelompok usaha ini sebagai mitra dikarenakan kelompok usaha Bukit Bengkulu yang merupakan home industry di bawah binaaan yayasan swasta Lembaga Pembibitan Pertanian Baptis adalah perintis berdirinya kelompok industri pengolahan sirup Kalamansi di Bengkulu, sedangkan kelompok usaha Putri Bengkulu merupakan home industry sirup Kalamansi terdekat dengan Universitas Bengkulu. Menurut informasi data dari Johan (Ketua kelompok Bukit Bengkulu) telah memiliki lahan perkebunan jeruk Kalamansi seluas \pm 3 Ha dengan pengelola usaha berjumlah 7 orang. Sedangkan menurut informasi Prawoto (Ketua kelompok Putri Bengkulu), kelompok usaha ini memiliki lahan perkebunan jeruk Kalamansi seluas \pm 2 Ha yang beranggotakan 4 orang dengan jumlah pekerja sebanyak 2 orang (tetap). Kedua kelompok industri ini telah mampu menghasilkan buah jeruk Kalamansi sebanyak 25 ton per tahun dan memproduksi sirup Kalamansi sebanyak 12-13 ton per tahun. Kedua industri ini telah menggunakan alat dalam mengolah jeruk menjadi sirup sehingga setiap hari mampu mengolah $\pm 200 \mathrm{~kg}$ buah jeruk Kalamansi.

Dalam industri pengolahan jeruk menjadi sirup ini sudah tentu menghasilkan limbah (residu). Residu yang dihasilkan berupa kulit jeruk yang berasal dari jeruk yang telah diambil airnya (diperas), dan berupa serat kasar (ampas) hasil pemisahan air perasan. Ampas yang berupa serat kasar bercampur minyak ini diperoleh dari hasil dekantasi air perasan jeruk yang telah didiamkan selama 1-2 jam. Selama ini, para pelaku industri akan membuang kulit jeruk ini ke lingkungan (di sekitar tempat pengolahan), begitu juga dengan ampas air perasan jeruk yang hanya dikumpulkan saja dan belum dimanfaatkan. Padahal di dalam kulit Jeruk Kalamansi ini mengandung senyawa essensial yaitu minyak atsiri. Demikian juga halnya dengan ampas (serat kasar) yang bercampur minyak yang berada diatas air perasan jeruk yang diduga banyak mengandung minyak atsiri.

Dalam sehari, limbah kulit jeruk yang bisa dihasilkan dari industri sirup Kalamansi Bukit Bengkulu sebanyak $120 \mathrm{~kg}$ sedangkan serat kasar (ampas) yang dihasilkan sebanyak 15 liter/hari. Adanya residu/limbah yang dihasilkan pada produksi sirup Kalamansi ini ikut diperhitungkan dalam biaya produksi, sedangkan harga penjualan di pasaran tetap dijaga 
semurah mungkin akibatnya nilai keuntungan penjualan tidak maksimal. Selain itu residu kulit jeruk yang menumpuk akan menggangu pemandangan dan menimbulkan pencemaran.

Minyak atsiri jeruk dapat digunakan sebagai pengharum ruangan dan bibit parfum serta juga bermanfaat bagi kesehatan, yaitu untuk aromaterapi. Aroma jeruk dapat menstabilkan sistem syaraf, menimbulkan perasaan senang dan tenang, meningkatkan nafsu makan, dan menyembuhkan penyakit. Manfaat bagi kesehatan tersebut karena minyak atsiri jeruk mengandung senyawa limonen yang berfungsi melancarkan peredaran darah, meredakan radang tenggorokan dan batuk, serta menghambat sel kanker. Minyak atsiri jeruk juga mengandung linalool, linalil, dan terpineol yang memiliki fungsi sebagai penenang (sedatif), serta sitronela sebagai penenang dan pengusir nyamuk (Istianto, 2008).

Mengingat banyaknya manfaat dari minyak atsiri, maka sangat disayangkan jika limbah ini tidak dimanfaatkan secara optimal. Minyak atsiri yang diperoleh, nantinya dapat digunakan sebagai bibit/sediaan dalam pembuatan berbagai macam produk misalnya minyak angin aromaterapi, pengharum ruangan, pembuatan sabun cair antiseptik dan sebagainya.

\section{METODE PENGABDIAN}

Kegiatan Pengabdian Masyarakat ini dilaksanakan pada dua kelompok usaha pembuatan sirup Kalamansi yaitu kelompok usaha Bukit Bengkulu dan kelompok tani Putri Bengkulu yang terletak di Kabupaten Bengkulu Tengah, Provinsi Bengkulu. Kegiatan tersebut dilaksanakan selama 8 (delapan) bulan mulai dari bulan April hingga Nopember 2016. Untuk mencapai tujuan kegiatan pengabdian pada masyarakat ini digunakan metode sebagai berikut:

1. Penyampaian informasi, diskusi dan tanya jawab yang bertujuan untuk meningkatkan wawasan masyarakat tentang apa itu minyak atsiri, kegunaan dan nilai jual minyak atsiri serta jenis produk yang dapat dibuat menggunakan minyak atsiri diantaranya minyak angin aromaterapi dan sabun cair antiseptik.

2. Pelatihan teknik ekstraksi minyak atsiri pada masing-masing mitra. Proses ekstraksi minyak atsiri dari limbah (residu) produk pengolahan Jeruk Kalamansi yang akan dilakukan pada masing-masing mitra menggunakan metode distilasi uap secara langsung (direct steam distillation). Distilasi adalah proses pemisahan yang paling sering digunakan dalam kehidupan sehari-hari. Distilasi sangat baik untuk memisahkan bahan-bahan alam yang berupa zat cair atau untuk memurnikan cairan yang mengandung pengotor (Wonorahardjo, 2013). Perangkat yang diperlukan pada metode detilasi uap secara langsung ini terdiri dari 2 buah ketel yang terbuat dari gelas atau stainless steel tergantung pada skala industri. Ketel yang digunakan pada kegiatan pengabdian ini dirancang dari stainless steel dengan kapasitas $100 \mathrm{~kg}$. Selain itu juga digunakan kondensor sebagai labu pendingin untuk mengembunkan uap minyak atsiri yang dihasilkan pada proses penyulingan. Kondensor juga dibuat dari stainless dengan 
pipa spiral dan turbular di dalamnya. Tetesan minyak atsiri bercampur uap air akan dipisahkan di dalam alat separator yang terbuat dari bahan gelas. Minyak atsiri murni akan ditampung dalam botol berwarna gelap. Instalasi alat destilasi minyak atsiri ini sangat cocok digunakan oleh kedua mitra karena dapat menampung residu kulit jeruk dan ampas dalam jumlah yang cukup besar. Di samping itu juga proses perakitannya tidak terlalu rumit sehingga mudah dilakukan.

3. Pelatihan dan pembuatan minyak angin aromaterapi. Pembuatan minyak angin aromaterapi menggunakan formulasi minyak angin komersil seperti Fresh Care yang berbentuk roll on. Bahan-bahan yang digunakan pada pembuatan minyak angin aromaterapi terdiri dari menthol kristal (20\%), camphor (4\%), minyak atsiri (5\%) dan pelarut sampai $100 \%$. Semua bahan dilarutkan dengan pelarut kemudian diaduk dan ditambahkan minyak atsiri sedikit demi sedikit, disaring dan selanjutnya dimasukkan ke dalam botol roll on dan ditutup rapat.

4. Pelatihan dan pembuatan sabun cair antiseptik. Sabun cair antiseptik dibuat menggunakan formula sabun cair standar berdasarkan prinsip saponifikasi (Formularium Kosmetika Nasional Indonesia, 1985). Bahan baku pembuatan sabun cair ini terdiri dari minyak kelapa, $\mathrm{KOH}$, Sodium Carboxy Methyl Cellulose (Na CMC), asam stearat, BHA dan akuades. Semua bahan ditimbang, dimasukkan minyak kelapa sebanyak $30 \mathrm{ml}$ ke dalam gelas kimia, kemudian ditambahkan kalium hidroksida $40 \%$ sebanyak $16 \mathrm{ml}$ sedikit demi sedikit sambil terus dipanaskan pada suhu $50^{\circ} \mathrm{C}$ hingga mendapatkan sabun pasta. Sabun pasta ditambahkan dengan $25 \mathrm{ml}$ akuades, lalu dimasukkan natrium karboksi metil selulosa yang telah dikembangkan dalam akuades panas dan diaduk hingga homogen. Lalu ditambahkan asam stearat, butil hidroksi anisol, dan diaduk hingga homogen. Selanjutnya ditambahkan minyak atsiri dan akuades kemudian diaduk hingga homogen. Sabun cair yang dihasilkan kemudian dimasukkan ke dalam wadah bersih yang telah disiapkan.

\section{HASIL DAN PEMBAHASAN}

Kegiatan pengabdian pada masyarakat ini dimulai dengan pembuatan instalasi destilasi minyak atsiri. Minyak atsiri yang banyak dihasilkan adalah berasal dari sisa ampas (residu) perasan Jeruk Kalamansi. Mitra kelompok usaha LPPB (Lembaga Pembibitan Pertanian Baptis), telah menggunakan mesin pemeras jeruk sehingga dari hasil perasan jeruk ini, dihasilkan residu (ampas) di bagian permukaan atas setelah dilakukan pendiaman, yang selama ini ampas (residu) hanya dibuang begitu saja. Sedangkan yang berasal dari kulit jeruk sendiri, atsiri yang dihasilkan tidak sesuai dengan yang diharapkan, hal ini kemungkinan karena kandungan minyak atsiri pada kulit jeruk sudah terbawa oleh sari buah jeruk sewaktu proses pemerasan. Gambar instalasi destilasi uap untuk pembuatan minyak atsiri dapat dilihat pada Gambar 1 dan 2 berikut. 


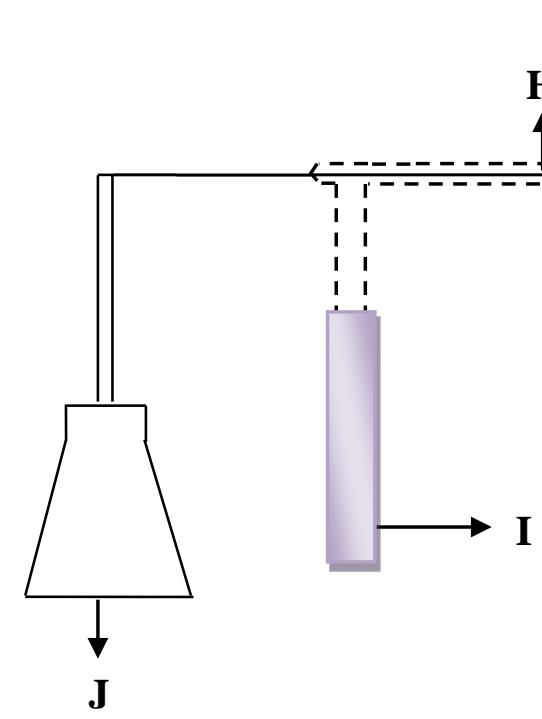

Gambar 1. Rancangan Alat Destilasi

Ket :
A. Kompor pemanas
F. Keran pembuka
B. Tungku pemanas
G. Air keluar
C. Ketel suling
H. Kondesor
D. Pressure gauge
I. Air masuk
E. Ketel pipa
J. Dekanter (penampung atsiri)

B

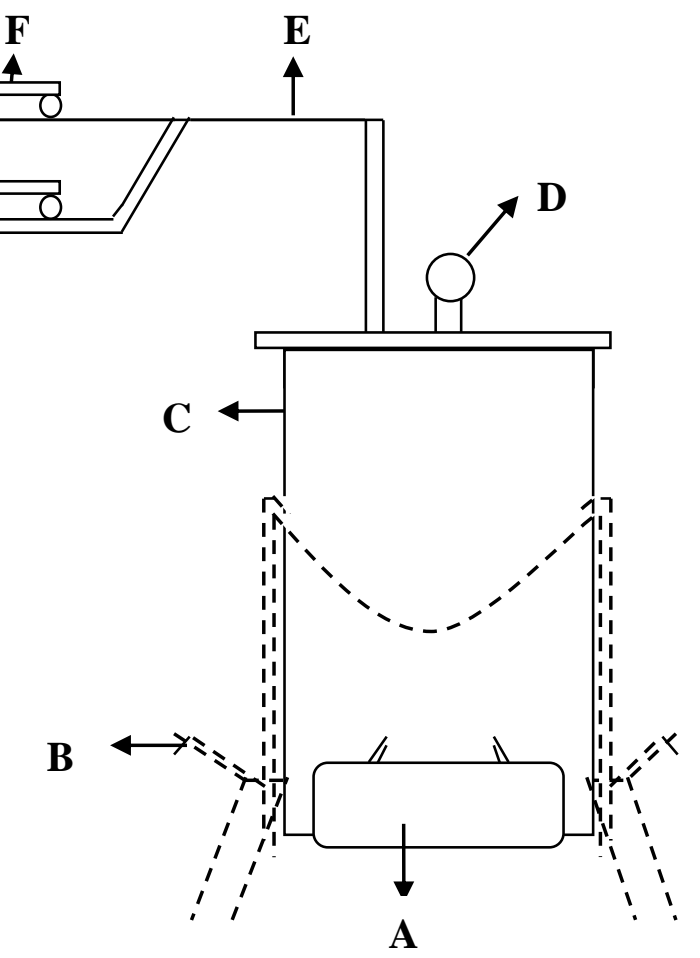




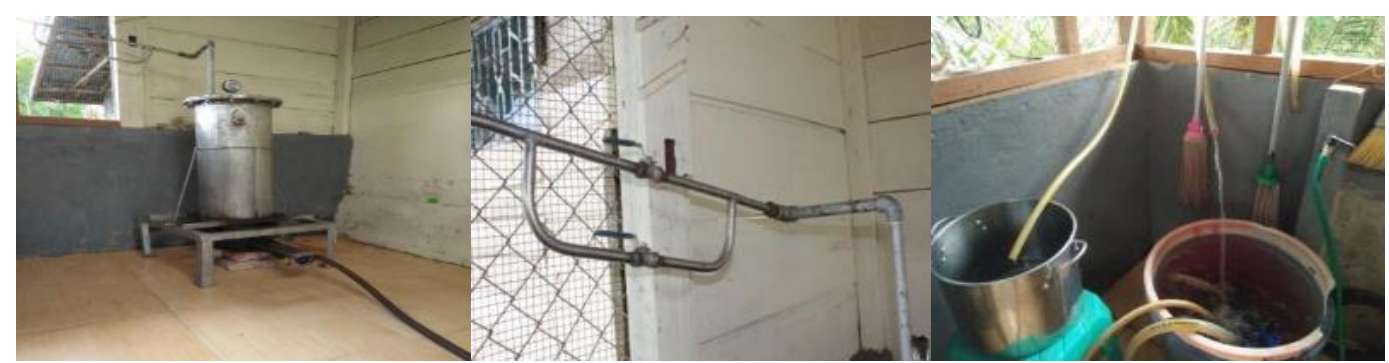

Gambar 2. Rangkaian alat ekstraktor minyak atsiri

Dari 200 kg Jeruk Kalamansi yang sudah diperas, maka dihasilkan 10 liter residu. Residu ini kemudian ditambahkan dengan 10 liter air, sehingga perbandingan residu dan air adalah 1:1. Setelah dilakukan proses distilasi, minyak atsiri yang diperoleh adalah 400 $\mathrm{ml}$, berwarna bening dan berbau khas Jeruk Kalamansi (Gambar 3).

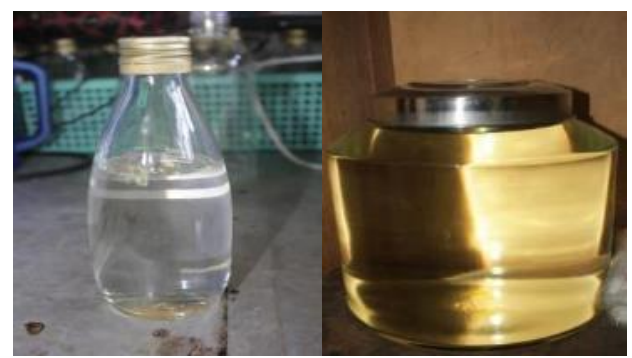

Gambar 3. Minyak atsiri dari residu pembuatan sirup Kalamansi

Kegiatan kemudian dilanjutkan dengan pelatihan pembuatan produk dari minyak atsiri yang telah diperoleh. Produk yang dibuat adalah minyak angin aromaterapi dan sabun cair. Kegiatan ini dimulai dengan tanya jawab mengenai apa itu minyak atsiri, kegunaan atau manfaatnya bagi kesehatan dan nilai ekonomi dari penjualan produk-produk yang menggunakan minyak atsiri. Dalam kegiatan ini, juga dibagikan hand out tentang komposisi bahan yang akan digunakan dalam pembuatan sabun cair dan minyak angin aromaterapi tersebut.

Selama kegiatan penyuluhan berlangsung, mendapatkan tanggapan positif dari ibuibu dan bapak-bapak anggota kelompok usaha LPPB dan Putri Bengkulu (Gambar 4). Hal ini terlihat dari peran aktif ibu-ibu dan bapak-bapak dalam menanggapi dan memberikan pertanyaan serta meminta penjelasan lebih lanjut mengenai materi yang disampaikan. Untuk pemahaman lebih lanjut mengenai pemanfaatan minyak atsiri dari residu pembuatan sirup Kalamansi selanjutnya dilakukan pelatihan pembuatan minyak angin aromaterapi roll on dan sabun cair (Gambar 4). Produk yang dihasilkan dapat dilihat pada Gambar 5. 


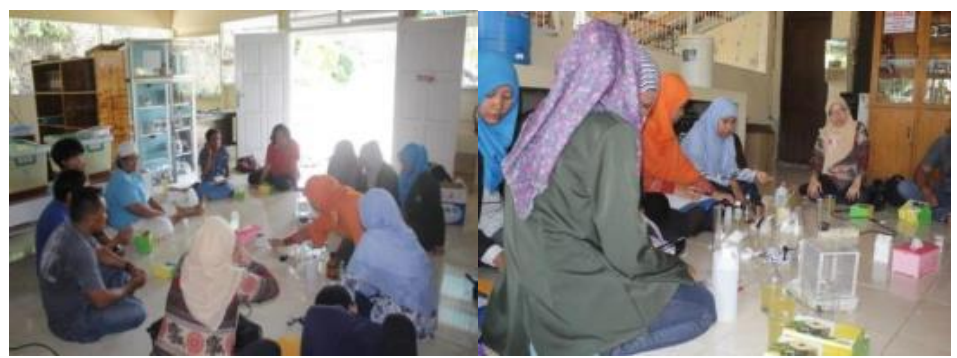

Gambar 4. Pelatihan dan diskusi tentang minyak atsiri dan pemanfaatannya

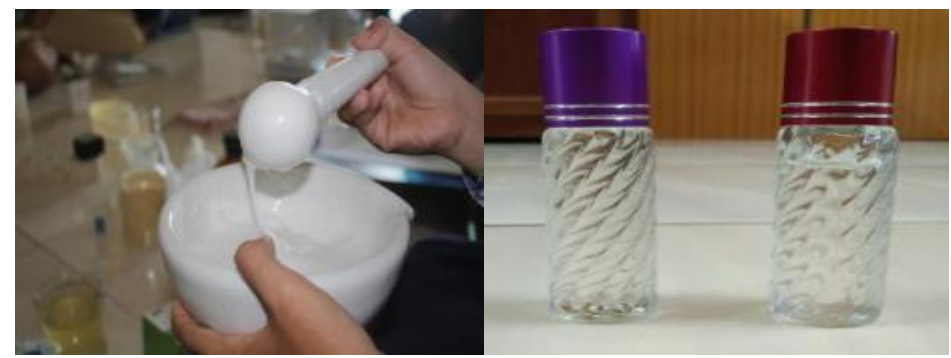

Gambar 5. Sabun cair (kiri) dan minyak angin aromaterapi (kanan)

\section{KESIMPULAN DAN SARAN}

\section{Kesimpulan}

Dari kegiatan pengabdian masyarakat ini, dapat disimpulkan bahwa:

1. Respon dari kedua mitra kelompok usaha LPPB dan Bukit Bengkulu sangat positif. Terbukti dari banyaknya pertanyaan dan diskusi berjalan dengan sangat menarik.

2. Dihasilkan minyak atsiri dari residu pembuatan sirup Kalamansi dengan residu sebesar $2 \%$ berupa cairan berwarna bening berbau khas Jeruk Kalamansi. Minyak atsiri yang dihasilkan ada senyawa limonen dengan kadar $100 \%$.

3. Dihasilkan beberapa produk berbahan aktif minyak atsiri Jeruk Kalamansi seperti minyak angin roll on, sabun mandi cair, lotion dan sabun cuci.

\section{Saran}

Untuk memperoleh manfaat yang maksimal dari kegiatan ini perlu adanya kegiatan berkelanjutan, untuk itu disarankan:

1. Pembinaan yang intensif bagi kelompok usaha LPPB dan Bukit Bengkulu untuk kepentingan pengembangan teknologi yang utuh maupun dari aspek pemasaran.

2. Perlu dilakukan pengembangan pemasaran dan promosi untuk pengembangan usaha, dan perlu bekerja sama dengan pihak penyedia modal untuk permodalan kelompok usaha sehingga dapat mengembangkan yang telah dirintis sebelumnya. 


\section{DAFTAR PUSTAKA}

Departemen Kesehatan Republik Indonesia, 1985, Formularium Kosmetika Nasional Indonesia, Cetakan Pertama, Departemen Kesehatan, Jakarta.

Istianto, M, 2008, Minyak Atsiri Jeruk: Peluang Meningkatkan Nilai Ekonomi Kulit Jeruk, Warta Penelitian dan Pengembangan Pertanian, Vol. 30 No. 6.

Muhtadin, A.F.R., Wijaya, R., Prihatini P., dan Mahfud, 2013, Pengambilan Minyak Atsiri dari Kulit Jeruk Segar dan Kering dengan Menggunakan Metode Steam Distillation, Jurnal Teknik Pomits Vol. 2, halaman 1, No. 1, 2013.

Sudarto, W.S., dalam Antara Bengkulu, 2012, Sirup Kalamansi Bengkulu Telah Merambah Dunia Internasional, Diposting pada Rabu 11 Jul 2012, 06.44.

Wonorahardjo, S., 2013, Metode-Metode Pemisahan Kimia, Akademia Permata, Jakarta. 